\title{
The Place of Technical Education towards Skill Acquisition to National Development
}

\author{
Ogundele, Alexander Gbenga \\ School of Technical Education, Kwara State College of Education (Technical), Lafiagi, Kwara State, Nigeria.
}

\begin{abstract}
Every sector of the economy requires one skill or the other while every job requires its own skill for the labor force. Many of these construction industries; manufacturing industries, production industries, and the education sectors are in daily need of skilled manpower to carry out one job or the other. As there are no jobs for the untrained, there are jobs for the highly skilled persons in the society. The growing concern over globalization among other things has made the acquisition of lifelong skills imperative for all categories of people. Acquisition of such skills can be acquired from technical education programs in the development of any nation. Skill acquisition provides knowledge and inculcates the attitudes that are necessary for entrance and progress into an occupation. When skills are acquired in any occupation, it will provide and improve the standard of living with the insurance against poverty, thereby sustaining national development. This paper examines how technical education can generate the required skills, the significance of skill acquisition, its roles, benefits and sustainability in national development. It also recommends among others that government should look into and improve programs that can encourage skill acquisition for the youths.
\end{abstract}

Keywords: National Development, Occupation, Skill Acquisition, Technical Education,

\section{Introduction}

The challenges of globalization and functional / knowledge education has paved way for the need for colleges to prepare students to be acquainted with the dawn of a new millennium which has raised in its wake, a burning and thirsty desire for attainment of technological competence in the world of work. This has to do with the provision of a functional technical education that will have equal and even distribution within the theoretical knowledge in real work situation thereby, bridging the gap between class or paper works and actual practical skills. It is quite glaring that no nation can develop without proper exploitation of her natural resources for the benefit of the people. The development of infrastructures (roads, railways, power, pipe borne water, communications, health care, etc.) is of paramount value to enhance the economy of such a nation. In order to make the economy grow, strong and stable in this era of global economic meltdown, we must increase the productivity of all factors of production (land, labor, capital, etc). This will inevitably lead to the development of the industrials, agricultural, tertiary health care and export sector of the economy. It will equally increase employment rate, national income and growth rate of the economy.

In Nigeria for instance, there is high level unemployment as asserted by Okoro (1993). He attributes it partly to the fact that people do not have the knowledge and skills that will enable them to take up the jobs that are available. He went further to say that,

'while there are no jobs for the untrained, there are many jobs for

the highly skilled. It has been said that Nigeria's development

program are being hampered by lack of skilled technical personnel...

in order to fill the vacancies that exist. It will also reduce the of

unemployment in the country. 'pp. 10

Ajibade (2009) observes that most computer graduates lack skills in their field. Akano in Ajibade (2009) supports that there is a skill gap in the area of computer engineering. He went further that the information and technology industry is confronted by knowledge deficiency noting that university graduates are only familiar with theory. Okafor in Ajibade (2009) asserts that there is a big gulf between what the school offer and the demand of employers. Harvey et al (2003) opines that employers want employees who can use their abilities and skills to evolve the organization. Development is like an exploration and utilization of both human and material resources to improve the lots of the nation. The place of skill acquisition cannot be over emphasized in the rapid development of other sectors of the economy. For this to be actualized proper skill acquisition polices and goals must be put in a place and well implemented.

\section{The Meaning of Technical Education}

The Federal Government of Nigeria (FGN) in its National Policy of Education (N.P.E., 2004) defines Technical Education as "that aspect of education, which leads to the acquisition of practical and applied skills as well as basic scientific knowledge". 
Ogundele (2010) defines Technical Education as "the aspect of knowledge, which involves special manipulative skills, creative minds, and attitudes required to practice a profession (occupation) for the benefit of that individual and the society". In line with this, the United Nations Educational, Scientific and Cultural Organization (UNESCO) in conjunction with International Labor Organization (ILO) 2002, observes among others concerning Technical Education as,
"a comprehensive term referring to those aspects of the educational process
involving, in addition to general education, the study of technologies and
related sciences, and the acquisition of practical skills, attitudes,
understanding and knowledge relating to occupations in various sectors of
economic and social life". p7.

The mind set is that individuals are trained to be self reliant, and well productive. This led to the formulations of the following goals of technical education in Nigeria.

The N.P.E. (2004) views technical education to be further understood as (a) an integral part of general education, (b) a means of preparing for occupational fields and for effective participation in the world of work; (c) an aspect of lifelong learning and a preparation for responsible citizenship; (d) an instrument for promoting environmentally sound sustainable development; (e) a method of alleviating poverty. (pg29).

\section{Skills Acquisition}

Skill is the ability to do something well, usually gained through training or experience that is needed while acquisition is the act of getting new knowledge, skill, etc. This skill can be obtained through education, training or experience that will inculcate into the individual how to carry out or discharge his / her responsibilities very well with the new knowledge. Work done by skilled people cannot be done by just anyone, unlike those task performed by unskilled people. The only irreplaceable capital and organization processes are the knowledge and ability of its people. The productivity of that capital depends on how effectively people share their competence with those who can use it.

When a skill is acquired in any discipline, it is assumed that the future gains that would result from it are of greater importance in terms of productivity.

\subsection{THE NEED FOR SKILL ACQUISITION}

Dike (2009) states that the impacts of economic calamity on nations depend on their level of development and effectiveness. An outline of core areas of skilled manpower needs can be listed thus:

1. Nigeria needs people who are skilled in modern agriculture methods to handle the use of modern equipment, new techniques in seed planting, land cultivation, harvesting and storage. These people will ensure that adequate food is produced for Nigerian's increasing population.

2. Nigerian is rapidly expanding her roads network system to improve the movement of goods and services. Such construction jobs require not only expert and dedicated workers, but skilled technicians who are able to operate and service the heavy duty equipment used in road construction.

3. Modern industries are being established in all parts of the country. These industries need skilled and welltrained workers to ensure that goods manufactured in Nigeria are as good as those manufactured in other parts of the world.

4. People need skills to operate and administered government and industrial operations. The expansions of both the public and private sectors in Nigeria means that more skilled workers in office management, accounting, typing and short-hand are required to ensure that accurate records are kept and that administrative efficiency is maintained.

5. Nigeria roads are full of all kinds of vehicles which assist in the economic development of the country by ensuring that goods and services are moved quickly and safely from one part of the country to another. These vehicles need efficient operatives and skilled technicians to ensure that they are operated safely and that their useful life is extended.

6. Skill acquisition is needed in the education sector. It contributes to the development of the nation's human capital and is seen as essential for preparing one for employment. Thus an educated man is expected to manifest worthwhile disposition in the society, for his own development and the development of the society. Ogunbote et al (2006) views that the productive capacity of any nation depends solely on her ability to recognize the capacity of manpower. The development of ideas, science advancement, technological breakthrough, economic development, political stability, and security is made possible by educational theories and practices.

7. Blackouts are routine in Nigeria. The bulk of power plants and transmission facilities were built in the 1950s and 1960s. little investment and maintenance have left the infrastructure creaking at the seams. Nigeria operates at one- third of its installed capacity due to aging equipment. It is very glaring that this 
sector needs manpower personnel with the appropriate practical skills, scientific knowledge, abilities and competencies for maintaining and securing power and energy.

Whatever the skill, attitudes, competencies, knowledge and understanding one acquires will enhance the development of the individual and the nation. According to the National Policy on Education [2004], one of the goals of education is the acquisition of appropriate skills and the development of mental, physical, and social abilities and competencies as equipment for the individual to live and contribute to the development of his society. Ogundele [2010] submits that;

'we need skilled personnel who will be enterprising and self reliant. We need skilled people who can understand and adapts to changes in the increasing complexity of technology. We need people who can apply scientific knowledge to improve and proffer solution to environmental challenges for the use and conveniences of man'. pp 10.

\subsection{SIGNIFICANCE OF SKILL ACQUISITION}

Two decades after Nigeria's independence, opportunities for employment abound for Nigerian graduates. In facts, it was the case that each recent graduate had at least three jobs from which to choose. Furthermore, the movement from school to job was virtually automatic. Today, it is very pathetic that the story line has changed as there is a disconnection between the world of learning and the world of work. Each job that appears in the labor market is now pursued by many old and new unemployed individuals because of the growing population. Datol and Padung (2000) assert that there are increasingly fewer occupational opportunities for the unfortunate youths who lack the basic skills and knowledge. By implication, unemployment rate will increase which will be a menace to the society, thereby, slowing down the pace of development because of untapped potentials or talents that are lying idle. Therefore, there is the need for the unemployed individuals to learn and acquire new skills which would make them self-employed by setting up their own businesses to create jobs for others too. In some cases, where the few ones get a job, they are trained to acquire special skills before they can go ahead with the new job. Ogundele (2010) opines that skill acquisition help people already on a job; intending to work in any of the varieties of occupations needed by the society. There is no job that does not require its own skill for manpower development.

The importance of skill acquisition to the development of the nation is of no small measure. Many of these construction industries, manufacturing industries, production industries, etc, are in daily need of trained personnel, technicians, technologists, engineers, etc, to carry out one job or the other. Okoro (1993) is of the view that our industries need skilled and well-trained workers to ensure that goods manufactured in Nigeria are as good as those manufactured in other parts of the world.

\subsection{EXPECTED OUTCOMES OF SKILL ACQUISITION}

The skill acquired by will prepare young people for any specific job with a lifelong opportunity for self development. This is because there will be competency, interest and job satisfaction to the highly skilled person to effectively and efficiently carry out that job successfully for higher productivity. The acquisition of skills will prepare the individual to fit in readily to employment in all sectors of the economy.

Skill acquisition can help in the formulation of ideas, their integration for national development and the interaction of persons and ideas. Prompt application of appropriate skill acquired would no doubt help to solve many of the perennial challenges arising from inadequacies and deficiencies of the traditional methods of teaching related subjects in our various institutions of learning.

\subsection{IT'S BENEFITS TO NATIONAL DEVELOPMENT.}

The acquisition of skills for a particular job will provide for people who could apply relevant knowledge to be able to make positive changes within the society. Skill acquisition in other words could advance the nation in the following ways:

A. Building in the individuals the essential skill to become useful within the society. Since a well-trained worker will be much more productive as an individual within the society, such an individual will no longer be a burden to the nation.

B. Make an individual to cultivate better attitude to work. Having got the necessary productive skills of doing or carrying out things the way they should, positive contributions can be made to the nation based upon the right attitude to work.

C. Jobs can be generated in abundance only if the acquired skills are derived and put in to use, giving rooms for the citizenry to think positively along the path of economic advancement.

D. Skill acquisition will eradicate involuntarily and unproductively idleness for national development.

E. Any individual who acquires skill will be able to show case his / her talents, make intelligent use of the brain in terms of new discoveries and innovation that will even upgrade individual status within the society. 
F. Once citizens of such a nation acquired adequate skills to turn around their economy, there would not be the need to waste billons of naira in bringing in some experts from overseas.

\subsection{IMPLICATION OF SKILL ACQUISITON TO NATION BUILDING}

When a skill is acquired in any discipline, it is assumed that the future gains that would result from it are of greater significance to productivity.

The growing concern over globalization, among other things, has made the acquisition of lifelong skills imperative for all categories of people. This is considered very important for future professionals' growth because it will determines how successful and productive a person will be in the work place. Shaffer (1997) observes that human capital is created when they acquire transferable skills that can be applied in many settings and occupations. It is an important index of sustainable development of any nation. In view of this, Anderson (1999) considers it as both a social prerogative and an economic necessity. With skill acquisition, one acquires capabilities to compete favorably within the context of globalization.

\section{Conclusion and Recommendations}

We need to equip our youths and working adult with employment skills and knowledge to meet the increasing demand for technical manpower by various sectors of the nation's economy either through formal, non-formal or informal training. The practical skill-based training should be enhanced through standardization of the qualifications obtainable under the frame work. These qualifications should be in strengthened into the nation's educational system for vertical or horizontal articulation.

\section{Recommendations}

The world is embracing a knowledge-based economy. We need to acquire more knowledge and skills for economic growth because every sector needs better skills to keep it running.

$\checkmark \quad$ There should be more practical work to complement theory in our tertiary institutions of learning, to provide skilled labor for the economy.

$\checkmark \quad$ Enough training facilities need to be provided to replace obsolete training equipment in this era of digitalization, in order to meet modern standard.

$\checkmark \quad$ The wide gap between the classroom and the industry should be bridged by skill acquisition policy in every ramification. The ratio of theoretical to practical should be 30:70 because you learn what you see, you remember what you touch.

$\checkmark \quad$ Secondary and post secondary institutions curricula should be developed to suit the demands of labor market.

$\checkmark \quad$ The Student Industrial Work Experience Scheme (SIWES) should be strengthened to meet up with its aims and objectives. This could be extended to senior secondary schools level during their vacation period while the fresh graduates go for one year Industrial Training Program (I.T.P) before the National Youth Service Corps (N.Y.S.C) training program just like the medical students that normally embark on one year houseman ship before the N.Y.S.C. program.

$\checkmark \quad$ Uneducated youths should be equipped with such skills as repair skills, possession of maintenance skills, possession and technical skills know how, Accounting and record keeping skills and procedures of operation skills in order for them to be self-reliant.

$\checkmark \quad$ Government should look into and improve programs that will encourage skill acquisition for our youths.

\section{References}

[1]. Ajibade, A. (2009). More graduates, less skills, http:// www.skill/com dated 30/11/2009

[2]. Anderson, D. (1999), "Navigating the Rapids: The Role of Education and Career information and Guidance in Transitions between Education and Work: Ajournal of Vocational Education and Training. Vol.5 (3) pp 371-399.

[3]. Datol, I.G. and Padung, L.L.(2002). Vocational and Technical Education - Away out of Nigerians future generation Jos: Zimleck Comms.

[4]. Dike, V. (2009). Global- economic crisis and power, http:// www.nigeriavillagesquare.com

[5]. Federal Republic of Nigeria (2004 Revised): national Policy on Education $\left(4^{\text {th }}\right.$ Edition), Lagos : NERDC Press, Yaba- Lagos.

[6]. Harvey, L. \& Bowers- Brown, T. (2003). The Employability of Graduates: Cross Comparison; Paper presented at DFES Research Conference 2003, London.

[7]. Ogunbote, Shefiu; Zosu, S. J. \& Ajibade, T. O. (2006). UBE: The impact of Technology Eucation for Nation Building. Nigerian Association of Teachers of Technology Journal, Vol.8, pp 108.

[8]. Ogundele, A.G. (2010). Higher Education and Employability in the International Labor Market. The Need for Technical Education. A paper presented at the $1^{\text {st }}$ International Conference organized by collaboration of Education faculties in West Africa (CEFWA) from $8^{\text {th }}-11^{\text {th }}$ February, 2010 at the University of Ilorin.

[9]. Okoro, O. M (1993). Principles and Methods in Vocational and Technical Education: Nsukka University Trust Publisher. Pp. 10-11; pp 15, pp 88 .

[10]. Shaffer, L. S (1997). "A Human Capital Approach to Academic Advising”. National Academic Advising Association Journal.17. pp. $5-12$. 